\title{
Рівень аполіпопротеїну А1 у хворих на цүкровий діабет і коморбідні захворювання на тлі COVID-19
}

Л.К. Соколова, Ю.Б. Бельчіна, С.А. Черв'якова, В.В. Пушкарьов, О.В. Фурманова, O.І. Ковзун, В.М. Пушкарьов, М.Д. Тронько

ДУ «Інститут ендокринології та обміну речовин ім. В.П. Комісаренка НАМН України»

Резюме. Підвищений рівень холестерину ліпопротеїнів високої щільності (ЛПВЩ) та аполіпопротеїну А1 (АроА1) у плазмі асоціюється зі зниженим ризиком розвитку серцево-судинних захворювань (СС3). Окрім потенційної кардіопротекторної функції, ЛПВЩ та АроА1, основні аполіпопротеїни ЛПВЩ, також мають протидіабетичні властивості. Мета. Метою дослідження було визначити рівень АроА1 у крові хворих на цукровий діабет (ЦД), коронавірусну інфекцію 2019 року (COronaVIrus Disease 2019, COVID-19) та інші супутні захворювання ( $n=81)$, а також вплив цукрознижувальних препаратів на рівень АроA1. Матеріал і методи. АроА1 визначали за допомогою наборів для імуноферментного аналізу («Elabscience», США); вимірювання проводили при оптичній довжині хвилі 450 нм. Результати. Рівень АроA1 у крові хворих на ЦД і, особливо, на COVID-19 був значно нижчим, ніж у крові здорових людей. На рівень АроА1 впливають супутні захворювання. Хронічний автоімунний тиреоїдит (ХАТ), хронічна ниркова недостатність (ХНH) та артеріальна гіпертензія (АГ) призводять до вірогідного зниження рівня АроА1 в крові. Лікування метформіном, або у вигляді монотерапії, або в поєднанні з іншими препаратами (переважно інсуліном), суттєво не впливає на рівень АроА1 порівняно зі середнім показником для всієї групи. У хворих, які отримували сульфонілсечовину (СС), рівень АроА1 значно нижчий від середнього рівня для групи та норми. Значний позитивний вплив на кількість АроА1 у плазмі спостерігався у хворих, які отримували комбінацію препаратів з інгібіторами натрійзалежного котранспортера глюкози-2 (Н3KГ-2i, sodium/glucose cotransporter 2 inhibitors, iSGLT2) та, особливо, інгібіторами дипептидилпептидази-4 (ДПП-4і, dipeptidyl peptidase-4 inhibitors, DPP-4і). Обговорюються можливі механізми зниження рівня ApoA1 за умов захворювання на COVID-19 та ЦД. Висновок. Таким чином, рівень АроA1 може бути одним із перспективних маркерів тяжкого перебігу COVID-19.

Ключові слова: аполіпопротеїн A1, COVID-19, цукровий діабет, серцево-судинні захворювання, гіпоглікемічні засоби.

ApoA1, основний білковий компонент ЛПВЩ, є поліпептидом із 243 амінокислот і молекулярною масою 28 кДа. Частинки ЛПВЩ, що циркулюють, містять одну або кілька копій

(С) Л.К. Соколова, Ю.Б. Бельчіна, С.А. Черв'якова, В.В. Пушкарьов,

О.В. Фурманова, О.І. Ковзун, В.М. Пушкарьов, М.Д. Тронько
ApoA1 [1]. АроA1 синтезується переважно в печінці та тонкому кишківнику [2].

Окрім своєї ролі в структурі ЛПВЩ, АроА1 також важливий для їх функціональності. АроА1 у безліпідній формі та в незрілій, бідній на ліпіди формі - пре- $\beta 1$-ЛПВЩ, яка 
COVID-19

складається переважно з АроА1 та фосфоліпідів із молекулярною масою 60-70 кДа, сприяє виходу холестерину за допомогою транспортеру ABCA1 (АТФ-зв’язуюча касета А1) з пінистих клітин, що утворюються 3 макрофагів, i, таким чином, ініціює зворотний транспорт холестерину з цих клітин, що полегшує поглинання його печінкою та, зрештою, виведенням холестерину кишківником [1,3].

Останні дані свідчать про те, що, регулюючи клітинний гомеостаз холестерину, ЛПВЩ та АроА1 можуть також регулювати запальні реакції в ендотеліальних клітинах та інших типах клітин, що активуються прозапальними подразниками в артеріальній інтимі [3, 4].

Було встановлено, що підвищений рівень ЛПВЩ та АроА1 у плазмі асоціюється зі зниженим ризиком розвитку ССЗ. Окрім потенційної кардіопротекторної функції, ЛПВЩ та АроА1 також характеризуються протидіабетичними властивостями. Підвищення рівня ЛПВЩ i ApoA1 у плазмі покращує глікемічний контроль у хворих на ЦД 2-го типу внаслідок посилення функції $\beta$-клітин підшлункової залози та підвищення чутливості до інсуліну. Отже, лікування, що підвищує рівень ЛПВЩ, може бути корисними при СС3, пов'язаних із ЦД [5, 6]. АроА1 також стимулює поглинання глюкози in vivo в скелетних та серцевих м'язах [7].

Встановлено, що співвідношення АроВ/ АроА1 асоційоване з ЦД 2-го типу і пропонується як новий біомаркер для його прогнозування [8]. Метааналіз також показує, що зниження рівня АроА1 та підвищення рівня АроB, а також співвідношення АроВ/А1 є факторами ризику першого ішемічного інсульту [9].

Кілька клінічних випробувань із використанням інфузійної терапії ЛПВЩ/АроА1 продемонстрували обнадійливі результати. Застосування генетичного перенесення є альтернативним способом використання корисних серцево-судинних ефектів ЛПВЩ/АроА1 на додаток до інфузійної терапії ЛПВЩ [10].

Метою дослідження було визначити рівень ApoA1 у крові хворих на ЦД, COVID-19 та інші супутні захворювання.

\section{Матеріал і методи}

Дослідження проводилось у відділі діабетології ДУ «Інститут ендокринології та метаболізму ім. В.П. Комісаренка НАМН України». Протокол дослідження було затверджено Комітетом з етики установи. Усі хворі підписали інформовану згоду на проведення подальших діагностичних і наукових досліджень. У процесі виконання дослідження дотримувались принципів біоетики: основних положень Конвенції Ради Європи про права людини та біомедицину від 04.04.1997 р., належної клінічної практики (Good Clinical Practice, GCP) від 1996 р., Гельсінської декларації Всесвітньої медичної асоціації про етичні принципи проведення наукових медичних досліджень за участю людини (1964-2000 рр.) і наказу Міністерства охорони здоров’я України № 281 від 01.11.2000 р.

Основну групу обстежених склали 60 хворих (35 жінок і 25 чоловіків) на ЦД 1-го $(\mathrm{n}=18)$ i 2-го $(\mathrm{n}=42)$ типів із різною коморбідною патологією, 8 з яких мали в анамнезі COVID-19 та 21 хворий (13 жінок і 8 чоловіків) на ЦД, CC3 та COVID-19. ЦД діагностували згідно критеріїв Американської діабетичної асоціації (American Diabetes Association, ADA), оновлених у 2021 р. Діагностику та лікування коморбідних захворювань проводили згідно протоколів, затверджених Міністерством охорони здоров'я України. Як контроль використовували кров здорових людей $(\mathrm{n}=7)$ без супутніх захворювань, репрезентативних за віком і статтю.

Хворі досліджувальних груп були репрезентативні за віком, статтю, тривалістю захворювання на ЦД і станом компенсації вуглеводного обміну. Середній вік хворих становив 61,4 роки (30-72 роки).

Кров отримували за допомогою стандартної венепункції та зберігали в пробірках з ЕДТА. Плазму відокремлювали центрифугуванням протягом 1 год після забору крові. Зразки зберігали при $-80{ }^{\circ} \mathrm{C}$ до використання. АроА1 визначали $(\mathrm{n}=81)$ за допомогою набору для імуноферментного аналізу («Elabscience», США). Вимірювання проводили при оптичній довжині хвилі 450 нм на імуноферментному планшетному аналізаторі Stat Fax 3200 («Awareness Technology», CШA) [11].

Глікований гемоглобін (Hb1Ac) визначали за допомогою набору One HbA1c FS («DiaSys Diagnostic Systems GmbH», Німеччина). Вимірювання проводили при оптичній довжині хвилі 660 нм. 
Статистичний аналіз даних проводили за допомогою програмного забезпечення Origin 7.0. Результати дослідження представлені як $\mathrm{M} \pm \mathrm{m}$ (n). Для порівняння груп даних використовували t-тест Стьюдента. Значення вважали вірогідними при $\mathrm{p} \leq 0,05$.

\section{Результати і обговорення}

У хворих на ЦД рівень Нb1Ас становив

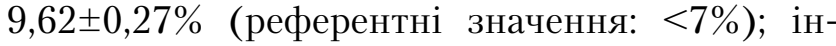
декс маси тіла $-30,69 \pm 1,06$ кг $/ \mathrm{M}^{2}$ (референт-

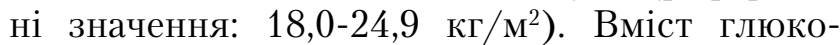
зи натще в крові хворих на COVID-19 та ЦД становив 9,6 $\pm 0,92$ ммоль/л (референтні значення: 4,4-7,2 ммоль/л), на момент виписки $6,72 \pm 0,62$ ммоль/л. Середнє насичення $\mathrm{O}_{2}$ у хворих на COVID-19 становило 87,3 $\pm 0,7 \%$ (референтні значення: $>94 \%$ ), що свідчить про важкий перебіг захворювання.

Середній рівень АроА1 у крові здорових

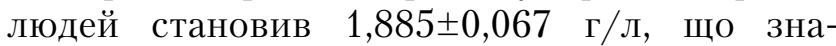
ходиться у верхньому діапазоні норми (референтні значення: 2,02-2,25 г/л) (табл. 1). У хворих на ЦД цей показник значно нижчий 1,211 $\pm 0,041$ г/л, що ближче до нижньої межі норми (1,04-1,08 г/л), а у хворих на ЦД після одужання від COVID-19 - 0,976 $\pm 0,020$ г/л, що нижче норми. Не спостерігалося вірогідної різниці рівнів АроА1 в плазмі хворих на ЦД 1-го та 2-го типів $(1,27 \pm 0,042$ г/л та $1,19 \pm 0,050$ г/л відповідно).

У хворих на ЦД та COVID-19 вміст ApoA1 у крові становить приблизно 0,25 г/л, що більш ніж у 4 рази нижче норми та в 7,5 раза нижче контрольних значень. Цікаво, що відмінності між хворими на COVID-19 і ЦД або CC3 та хворими лише на COVID-19 відсутні (табл. 1, група 3).

У крові деяких хворих на COVID-19 рівень АроА1 знизився майже до нульових значень 0,09 г/л. Той факт, що рівень АроА1 у крові не знижується у хворих на COVID-19, ЦД і CC3 порівняно з хворими без супутніх захворювань, свідчить про те, що COVID-19 створює комплекс значно потужніших факторів, які впливають на вміст АроА1, і таке зниження досягає межі. Слід зазначити, що після одужання від COVID-19 рівень АроА1 відновлюється, хоча і залишається нижче рівня у хворих на ЦД (табл. 1, групи 2 та 3 ).
Таблиця 1. Рівень АроА1 у плазмі крові у хворих на ЦД, ССЗ i COVID-19

Table 1. Plasma ApoA1 levels in patients with diabetes mellitus (DM), cardiovascular diseases and COVID-19

\begin{tabular}{|c|c|c|}
\hline № & $\begin{array}{l}\text { Групи } \\
\text { Groups }\end{array}$ & $\begin{array}{l}\text { ApoA1 (г/л) } \\
\text { ApoA1, g/L }\end{array}$ \\
\hline 1 & $\begin{array}{l}\text { Контроль } \\
\text { Control }\end{array}$ & $\begin{array}{l}1,885 \pm 0,067 \\
(7)\end{array}$ \\
\hline 2 & $\begin{array}{l}\text { Хворі на ЦД } \\
\text { Patients with DM }\end{array}$ & $\begin{array}{l}1,211 \pm 0,041 \\
(60)^{*}\end{array}$ \\
\hline 3 & $\begin{array}{l}\text { Хворі на ЦД після перенесеного COVID-19 } \\
\text { Patients with DM after COVID-19 }\end{array}$ & $\begin{array}{l}0,976 \pm 0,020 \\
(8)^{* \#}\end{array}$ \\
\hline 4 & $\begin{array}{l}\text { Хворі на ЦД і COVID-19 } \\
\text { Patients with DM and COVID-19 }\end{array}$ & $\begin{array}{l}0,257 \pm 0,022 \\
(16)^{* \# \#}\end{array}$ \\
\hline 5 & $\begin{array}{l}\text { Хворі на COVID-19 } \\
\text { Patients with COVID-19 }\end{array}$ & $\begin{array}{l}0,258 \pm 0,044 \\
(5)^{* \# \#}\end{array}$ \\
\hline 6 & $\begin{array}{l}\text { Хворі на COVID-19, ЦД і СС3 } \\
\text { Patients with COVID-19, DM and } \\
\text { cardiovascular diseases }\end{array}$ & $\begin{array}{l}0,294 \pm 0,006 \\
(5)^{* \# \#}\end{array}$ \\
\hline
\end{tabular}

Примітка: * - вірогідна різничя порівняно з групою $1(p<0,0001)$; "- вірогідна різничя порівняно з групою $2(p<0,05)$;

\#\# - вірогідна різниця порівняно з групами 2 і 3 ( $p<0,001)$.

Note: ${ }^{*}$ - significant difference compared with the group $1(p<0.0001)$;

\# - significant difference compared with the group $2(p<0.05)$;

\#\# - significant difference compared with the groups 2 and $3(p<0.001)$.

У хворих на ЦД 2-го типу з інсулінорезистентністю часто спостерігаються дисліпідемія [12]. Зниження рівня АроА1 у крові хворих на ЦД та збільшення ризику ССЗ було відзначено в багатьох дослідженнях [13-15]. Було встановлено взаємозв'язок вмісту ЛПВЩ й AроА1 у сироватці крові з ризиком розвитку важкої інфекції SARS-CoV-2 [16].

AроА1 було визначено як ініціювальний фактор білкового комплексу, а білок амілоїду бета A4 (amyloid beta A4 protein, APP), епідермальний фактор росту (epidermal growth factor, EGF) і комплемент C3 були основними критичними елементами в цій мережі. АроА1 має протизапальні властивості, які можуть сприяти регуляції імунної відповіді. Отримані дані вказують на те, що підвищення кількості комплементу С3 та зниження кількості АроА1 у сечі впливають на ригідність дихання i, отже, на тяжкість COVID-19 [17]. До того ж порушення регуляції білка амілоїду бета А4 та АроА1 може сприяти виникненню можливих побічних ефектів COVID-19 у нервовій системі [18].

У плазмі хворих на COVID-19 суттєво зменшувався рівень АроА1, а також зазнавали значного впливу ліпідні профілі зі зниженням рівнів загального холестерину, ЛПВЩ і ліпопротеїнів низької щільності та підвищенням рівня 
COVID-19

тригліцеридів [11, 19]. Індукована COVID-19 гіполіпідемія позитивно корелювала 3 тяжкістю захворювання [20].

Зниження рівня АроА1 у хворих на COVID-19 свідчить про пригнічення його синтезу печінкою та/або заміщення сироваткового амілоїду A (serum amyloid A, SAA) у ЛПВЩ [19]. Також ці зміни були пов'язані 3 патогенезом хронічного пневмоніту, що призводить до легеневого фіброзу, та хімазою тучних клітин, яка послаблювала захисний ефект АроА1 проти фіброзу.

Ці результати свідчать, що хімаза, яка продукується тучними клітинами, може відігравати важливу роль у деградації АроА1 [2, 21]. Крім того, карбоксипептидаза А, матриксні металопротеїнази ММР-3 і ММР-14 також можуть брати участь у деградації АроА1 [21, 22].

Запальні цитокіни, такі як фактор некрозу пухлини (tumor necrosis factor, TNF) та інтерлейкін $1 \beta$ (interleukin 1 beta, IL-1 $\beta$ ), які виділяються у великих кількостях під час зараження COVID-19, пригнічують продукування АроА1 гепатоцитами та збільшують експресію SAA, який стає основним білковим компонентом ЛПВЩ [10]. Нарешті, down-регуляція експресії АроА1 може відбуватися на рівні транскрипції [23].

На рівень АроА1 впливають супутні захворювання. У першу чергу це ХАТ, ХНН і АГ (табл. 2). Зменшення кількості АроА1 і АроА2 за умов ХНН відмічалось раніше [24-26]. Дані щодо впливу ХАТ та вузлового зоба на концентрацію АроА1 обмежені, проте показано, що хронічні автоімунні захворювання призводять до зменшення концентрації АроA1 та зростання кількості SAA в крові хворих [27-29]. Відомо також, що при АГ спостерігається дисліпідемія і зниження рівня АроА1 в плазмі [30-32].

Рівень АроА1 залежить від методу лікування (табл. 3). Так, терапія метформіном у вигляді монотерапії або в поєднанні з іншими препаратами (переважно з інсуліном) суттєво не впливає на рівень АроА1 порівняно зі середнім показником для групи (групи 2, 3 та 9). Монотерапія інсуліном також не впливала на вміст АроА1 (група 8). У хворих, які отримували СС, рівень АроА1 був значно нижчим від середнього рівня для всієї групи та норми (група 4). Значний позитивний вплив щодо рівня АроА1 у плазмі спостерігався у хворих, які отримували комбінацію препаратів із НЗКГ-2і та, особливо, із ДПП-4і (групи 5 і 6).
Особливий інтерес представляє значне зниження рівня АроА1 порівняно зі середнім рівнем ліпопротеїну у хворих на ЦД після комбінованого лікування з СС. Деякі дослідники припускають, що препарати СС можуть впливати на серцеву функцію, а також можуть бути пов’язані з гіршими наслідками після інфаркту міокарда [33].

За останні десятиліття повідомлялося про збільшення смертності від ССЗ у хворих на ЦД, які приймали толбутамід. У клініці Мауо (Rochester, Minnesota, USA) у 185 хворих на ЦД, які перенесли інфаркт міокарда, коефіцієнт шансів на смерть становив 2,77 для хворих, які отримували препарати СС на момент інфаркту [33, 34].

Таблиця 2. Рівень АроА 1 у плазмі крові хворих на ЦД та супутні захворювання

Table 2. Plasma ApoA1 levels in patients with DM and comorbidities

\begin{tabular}{|c|c|c|}
\hline № & $\begin{array}{l}\text { Групи } \\
\text { Groups }\end{array}$ & $\begin{array}{l}\text { AроA1 (г/л) } \\
\text { AроA1, g/L }\end{array}$ \\
\hline 1 & $\begin{array}{l}\text { Контроль } \\
\text { Control }\end{array}$ & $\begin{array}{l}1,885 \pm 0,067 \\
(7)\end{array}$ \\
\hline 2 & $\begin{array}{l}\text { Середнє по групі } \\
\text { Group average }\end{array}$ & $\begin{array}{l}1,211 \pm 0,041 \\
(60)^{*}\end{array}$ \\
\hline 3 & $\begin{array}{l}\text { Хворі на ЦД і ХАТ } \\
\text { Patients with DM and chronic autoimmune } \\
\text { thyroiditis }\end{array}$ & $\begin{array}{l}1,017 \pm 0,026 \\
(14)^{* \#}\end{array}$ \\
\hline 4 & $\begin{array}{l}\text { Хворі на ЦД без ХАТ } \\
\text { Patients with DM without chronic } \\
\text { autoimmune thyroiditis }\end{array}$ & $\begin{array}{l}1,212 \pm 0,045 \\
(46)^{* \# \#}\end{array}$ \\
\hline 5 & $\begin{array}{l}\text { Хворі на ЦД і вузловий зоб } \\
\text { Patients with DM and goiter }\end{array}$ & $\begin{array}{l}1,264 \pm 0,050 \\
(14)^{*}\end{array}$ \\
\hline 6 & $\begin{array}{l}\text { Хворі на ЦД без вузлового зобу } \\
\text { Patients with DM without goiter }\end{array}$ & $\begin{array}{l}1,134 \pm 0,041 \\
(46)^{* \# \#}\end{array}$ \\
\hline 7 & $\begin{array}{l}\text { Хворі на ЦД і ХНН } \\
\text { Patients with DM and chronic renal failure }\end{array}$ & $\begin{array}{l}1,064 \pm 0,041 \\
(37)^{* \#}\end{array}$ \\
\hline 8 & $\begin{array}{l}\text { Хворі на ЦД без ХНН } \\
\text { Patients with DM without chronic renal } \\
\text { failure }\end{array}$ & $\begin{array}{l}1,268 \pm 0,037 \\
(23)^{* \# \#}\end{array}$ \\
\hline 9 & $\begin{array}{l}\text { Хворі на ЦД і АГ } \\
\text { Patients with DM and arterial hypertension }\end{array}$ & $\begin{array}{l}1,068 \pm 0,045 \\
(39)^{* \#}\end{array}$ \\
\hline 10 & $\begin{array}{l}\text { Хворі на ЦД без АГ } \\
\text { Patients with DM without arterial } \\
\text { hypertension }\end{array}$ & $\begin{array}{l}1,214 \pm 0,037 \\
(21)^{*} \#\end{array}$ \\
\hline
\end{tabular}

Примітка: * - вірогідна різниця порівняно з групою $1(p<0,0001)$; " - вірогідна різничя порівняно з усередненим значенням групи $2(p<0,05)$; $^{* *}$ - вірогідна різниця між групами 3 і 4 , 5 i 6,7 i 8,9 i 10 $(p<0,05)$.

Note: ${ }^{*}$ - significant difference compared with the group $1(p<0.0001)$; " - significant difference compared with the the average values of group $2(p<0.05) ; \#$ - significant difference between groups 3 and 4, 5 and 6, 7 and 8,9 and $10(p<0.05)$. 
Таблиця 3. Вплив лікування на рівень АроA1 у плазмі крові хворих на ЦД

Table 3. Effects of treatment on ApoA1 plasma value of patients with DM

\begin{tabular}{|c|c|c|}
\hline № & $\begin{array}{l}\text { Групи } \\
\text { Groups }\end{array}$ & $\begin{array}{l}\text { ApoA1 } \\
\text { ApoA1 }\end{array}$ \\
\hline 1 & $\begin{array}{l}\text { Контроль } \\
\text { Control }\end{array}$ & $1,885 \pm 0,067(7)$ \\
\hline 2 & $\begin{array}{l}\text { Середнє по групі } \\
\text { Group average }\end{array}$ & $1,211 \pm 0,041(60)^{*}$ \\
\hline 3 & $\begin{array}{l}\text { Комбінація з метформіном } \\
\text { Combination with metformin }\end{array}$ & $1,243 \pm 0,042(30)^{*}$ \\
\hline 4 & $\begin{array}{l}\text { Комбінація з СС } \\
\text { Combination with sulfonylurea }\end{array}$ & $0,794 \pm 0,092(9)^{* \#}$ \\
\hline 5 & $\begin{array}{l}\text { Комбінація з Н3КТTГ-2і } \\
\text { Combination with iSGLT2 }\end{array}$ & $1,329 \pm 0,065(8)^{* \#}$ \\
\hline 6 & $\begin{array}{l}\text { Комбінація з ДПП-4і } \\
\text { Combination with DPP-4i }\end{array}$ & $1,472 \pm 0,088(5)^{* \#}$ \\
\hline 7 & $\begin{array}{l}\text { Комбінація з інсуліном } \\
\text { Combination with insulin }\end{array}$ & $1,280 \pm 0,036(40)^{*}$ \\
\hline 8 & $\begin{array}{l}\text { Монотерапія з інсуліном } \\
\text { Monotherapy with insulin }\end{array}$ & $1,224 \pm 0,042(18)^{*}$ \\
\hline 9 & $\begin{array}{l}\text { Монотерапія з метформіном } \\
\text { Monotherapy with metformin }\end{array}$ & $1,223 \pm 0,090(6)^{*}$ \\
\hline \multicolumn{3}{|c|}{$\begin{array}{l}\text { Примітка: *_ вірогідна різниця порівняно з групою } 1 \text { ( } p<0,0001) \text {; } \\
\text { \#—_ірогідна різничя порівняно зусередненим значенням групи } 2 \text { (p<0,05). }\end{array}$} \\
\hline & $\begin{array}{l}: \text { * significant difference compared } \\
\text { ignificant difference compared with } t\end{array}$ & $\begin{array}{l}\text { the group } 1(p<0.0001) ; \\
\text { e average value of group } 2\end{array}$ \\
\hline
\end{tabular}

Крім того, висока доза глібенкламіду пригнічувала функцію АТФ-зв'язувальної касети підродини А члена 1 (АТP binding cassette subfamily A member 1, ABCA1) та опосередкований АроА1 відтік холестерину, а також послаблювала експресію АВСА1 [35], що може призвести до накопичення холестерину в макрофагах атеросклеротичних бляшок. Не виключено, що зниження рівня АроА1 може бути відображенням негативних процесів, що відбуваються під час лікування СС.

Навпаки, поєднання препаратів 3 інгібіторами НЗКГ-2 та ДПП-4 спричинило помітне підвищення рівня АроА1, що узгоджується з їх позитивним впливом на серцево-судинну функцію при ЦД [36, 37]. До того, глюкагоноподібний агоніст рецептора пептиду-1 (glucagon like peptide-1 receptor agonist, GLP-1RA), ДПП-4i та НЗКГ-2і позитивно впливають на ліпідний обмін при ЦД [38].

Монотерапія метформіном або інсуліном, а також лікування метформіном у поєднанні з іншими лікарськими засобами, суттєво не впливають на рівень АроА1. Комбіноване лікування інсуліном та іншими препаратами мало позитивний вплив на рівень АроА1. Вiдомо, що гіперінсулінемія є атерогенним фактором [39], але не виключено, що лікування інсуліном у поєднанні з ДПП-4і та НЗКГ-2і призводить до збільшення кількості АроА1 у плазмі. Позитивний вплив метформіну щодо серцево-судинної функції можливо пояснюється зниженням концентрацій ендотеліна-1 (endothelin-1, ET-1) та N-кінцевого фрагмента мозкового натрійуретичного гормона В-типу (N-terminal fragment of the BNP precursor, NTproBNP), а також збільшенням вмісту глюкагоноподібного пептиду-1 (glucagon-like peptide-1, GLP-1) за дії цих препаратів [40, 41].

\section{Висновки}

1. Рівень ApoA1 у крові хворих на ЦД і особливо з COVID-19 був значно нижчим, ніж у крові здорових людей. Рівень АроА1 може бути одним із перспективних маркерів важкого перебігу COVID-19.

2. На рівень АроА1 впливають супутні захворювання. Наявність АТ, ХНН та АГ призводять до зниження рівня ліпопротеїду в крові.

3. Лікування метформіном як у вигляді монотерапії, так і в поєднанні з іншими препаратами (переважно інсуліном) суттєво не впливає на рівень АроА1 порівняно зі середнім показником для всієї групи. У хворих, які отримували СС, рівень АроА1 значно нижчий від середнього рівня для групи та норми. Значний позитивний вплив на рівень АроА1 у плазмі спостерігався у хворих, які отримували комбінацію препаратів із НЗКГ-2і та, особливо, інгібіторів ДПП-4.

\section{Список використаної літератури}

1. Lund-Katz S, Phillips MC. High density lipoprotein structurefunction and role in reverse cholesterol transport. Subcell Biochem. 2010;51:183-227. doi: 10.1007/978-90-481-8622-8 7 .

2. Inoue Y, Okamoto T, Honda T, Nukui T, Takemura T, Tozuka M, et al Disruption in the balance between apolipoprotein A-I and mast cell chymase in chronic hypersensitivity pneumonitis. Immun Inflamm Dis. 2020 Dec;8(4):659-71. doi: 10.1002/iid3.355.

3. Kareinen I, Baumann M, Nguyen SD, Maaninka K, Anisimov A, Tozu$\mathrm{ka} \mathrm{M}$, et al. Chymase released from hypoxia-activated cardiac mast cells cleaves human apoA-I at $\mathrm{Tyr}^{192}$ and compromises its cardioprotective activity. J Lipid Res. 2018 Jun;59(6):945-57. doi: 10.1194/jlr.M077503.

4. Mineo C, Shaul PW. Regulation of signal transduction by HDL. J Lipid Res. 2013 Sep;54(9):2315-24. doi: 10.1194/jlr.R039479.

5. Rye KA, Barter PJ, Cochran BJ. Apolipoprotein A-I interactions with insulin secretion and production. Curr Opin Lipidol. 2016 Feb;27(1):8-13. doi: 10.1097/MOL.0000000000000253. 
COVID-19

6. Di Bartolo BA, Cartland SP, Genner S, Manuneedhi Cholan P, Vellozzi M, Rye KA, et al. HDL improves cholesterol and glucose homeostasis and reduces atherosclerosis in diabetes-associated atherosclerosis. J Diabetes Res. 2021 May 6;2021:6668506. doi: $10.1155 / 2021 / 6668506$

7. Fritzen AM, Domingo-Espín J, Lundsgaard AM, Kleinert M, Israelsen I, Carl CS, et al. ApoA-1 improves glucose tolerance by increasing glucose uptake into heart and skeletal muscle independently of AMPKa $\alpha_{2}$. Mol Metab. 2020 May;35:100949. doi: 10.1016/j.molmet.2020.01.013.

8. Mao Y, Xu Y, Lu L. The nonlinear association between apolipoprotein B to apolipoprotein A1 ratio and type 2 diabetes. Medicine (Baltimore). 2017 Jan;96(1): e5834. doi: 10.1097/ MD.0000000000005834. Erratum in: Medicine (Baltimore). 2017 Mar 24;96(12): e6541. Erratum in: Medicine (Baltimore). 2017 Apr 28;96(17): e6821.

9. Dong H, Chen W, Wang X, Pi F, Wu Y, Pang S, et al. Apolipoprotein A1, B levels, and their ratio and the risk of a first stroke: a meta-analysis and case-control study. Metab Brain Dis. 2015 Dec;30(6):1319-30. doi: 10.1007/s11011-015-9732-7.

10. Chyu KY, Shah PK. HDL/ApoA-1 infusion and ApoA-1 gene therapy in atherosclerosis. Front Pharmacol. 2015 Sep 1;6:187. doi: 10.3389/fphar.2015.00187.

11. Tronko MD, Cherviakova SA, Pushkarev VV, Belshina YV, Kovzun OI, Pushkarev VM, et al. Apolipoprotein A1 level in plasma of patients with diabetes and diabetic patients with COVID-19 as a possible marker of disease. Rep Nac Acad Sci Ukr. 2021;4:110-3. doi: 10.15407/dopovidi2021.04.110.

12. Wolkowicz P, White CR, Anantharamaiah GM. Apolipoprotein mimetic peptides: an emerging therapy against diabetic inflammation and dyslipidemia. Biomolecules. 2021 Apr 23;11(5):627. doi: 10.3390/biom11050627.

13. Cochran BJ, Ong KL, Manandhar B, Rye KA. High density lipoproteins and diabetes. Cells. 2021 Apr 9;10(4):850. doi: $10.3390 /$ cells10040850.

14. Gao L, Zhang Y, Wang X, Dong H. Association of apolipoproteins $\mathrm{A} 1$ and $\mathrm{B}$ with type 2 diabetes and fasting blood glucose: a crosssectional study. BMC Endocr Disord. 2021 Apr 1;21(1):59. doi: 10.1186/s12902-021-00726-5

15. Retnakaran R, Ye C, Connelly PW, Hanley AJ, Sermer M, Zinman B. Serum apoA1 (Apolipoprotein A-1), insulin resistance, and the risk of gestational diabetes mellitus in human pregnancy - brief report. Arterioscler Thromb Vasc Biol. 2019 Oct;39(10):2192-7. doi: 10.1161/ATVBAHA.119.313195.

16. Hilser JR, Han Y, Biswas S, Gukasyan J, Cai Z, Zhu R, et al Association of serum HDL-cholesterol and apolipoprotein A1 levels with risk of severe SARS-CoV-2 infection. J Lipid Res. 2021 Mar 2;62:100061. doi: 10.1016/j.jlr.2021.100061.

17. Zamanian Azodi M, Arjmand B, Zali A, Razzaghi M. Introducing APOA1 as a key protein in COVID-19 infection: a bioinformatics approach. Gastroenterol Hepatol Bed Bench. 2020 Fall;13(4):367-73.

18. Yang Y, Zhu Z, Fan L, Ye S, Lou K, Hua X, et al. Low serum level of apolipoprotein A1 is an indicator of severity in patients with coronavirus disease 2019. Preprint from Research Square; 2020 May 29. doi: 10.21203/rs.3.rs-31251/v1.

19. Begue F, Tanaka S, Mouktadi Z, Rondeau P, Veeren B, Diotel N, et al. Altered high-density lipoprotein composition and functions during severe COVID-19. Sci Rep. 2021 Jan 27;11(1):2291. doi: 10.1038/s41598-021-81638-1

20. Wei X, Zeng W, Su J, Wan H, Yu X, Cao X, et al. Hypolipidemia is associated with the severity of COVID-19. J Clin Lipidol. 2020 May-Jun;14(3):297-304. doi: 10.1016/j.jacl.2020.04.008.

21. Usami Y, Kobayashi Y, Kameda T, Miyazaki A, Matsuda K, Sugano M, et al. Identification of sites in apolipoprotein A-I susceptible to chymase and carboxypeptidase A digestion. Biosci Rep. 2012 Dec 6;33(1):49-56. doi: 10.1042/BSR20120094.

22. Park JH, Park SM, Park KH, Cho KH, Lee ST. Analysis of apolipoprotein A-I as a substrate for matrix metalloproteinase-14. Biochem Biophys Res Commun. 2011 May 27;409(1):58-63. doi: 10.1016/j.bbrc.2011.04.105.

23. Georgila K, Vyrla D, Drakos E. Apolipoprotein A-I (ApoA-I), immunity, inflammation and cancer. Cancers (Basel). 2019 Aug 1;11(8):1097. doi: 10.3390/cancers11081097.
24. Vaziri ND. Causes of dysregulation of lipid metabolism in chronic renal failure. Semin Dial. 2009 Nov-Dec;22(6):644-51. doi: 10.1111/j.1525-139X.2009.00661.x.

25. Zhang H, Shi S, Zhao XJ, Wang JK, Liu ZW, Liu FQ, et al. Association between the lipid profile and renal dysfunction in the heart failure patients. Kidney Blood Press Res. 2019;44(1):52-61 doi: 10.1159/000498834.

26. Barbagallo CM, Cefal AB, Giammanco A, Noto D, Caldarella R, Ciaccio M, et al. Lipoprotein abnormalities in chronic kidney disease and renal transplantation. Life (Basel). 2021 Apr 5;11(4):315. doi: 10.3390/life11040315.

27. Duarte-Delgado NP, Lujan TP, Arbeláez-Cortés Á, GarcíaValencia J, Zapata A, Rojas M, et al. Identification of levels of serum amyloid a and apolipoprotein A1 in serum proteomic analysis of neuropsychiatric systemic lupus erythematosus patients. Autoimmune Dis. 2018 Nov 21;2018:6728541. doi: $10.1155 / 2018 / 6728541$

28. Yuan J, Li LI, Wang Z, Song W, Zhang Z. Dyslipidemia in patients with systemic lupus erythematosus: Association with disease activity and B-type natriuretic peptide levels. Biomed Rep. 2016 Jan;4(1):68-72. doi: 10.3892/br.2015.544.

29. Chen W, Wang Q, Zhou B, Zhang L, Zhu H. Lipid metabolism profiles in rheumatic diseases. Front Pharmacol. 2021 Apr 9;12:643520. doi: 10.3389/fphar.2021.643520.

30. Khirfan G, Li M, Wang X, DiDonato JA, Dweik RA Heresi GA. Abnormal levels of apolipoprotein A-I in chronic thromboembolic pulmonary hypertension. Pulm Circ. $2021 \mathrm{Apr}$ 22;11(2):20458940211010371. doi: 10.1177/20458940211010371.

31. Purohit P, Mathur R. Hypertension association with serum lipoproteins, insulin, insulin resistance and C-Peptide: unexplored forte of cardiovascular risk in hypothyroidism. N Am J Med Sci. 2013 Mar;5(3):195-201. doi: 10.4103/1947-2714.109187.

32. Mei Z, Zhou S, Huang B, Mo Y, Hou H. Proteomic identification of candidate plasma biomarkers for preeclampsia in women with pregnancy-induced hypertension. Int J Clin Exp Pathol. 2017 Oct 1;10(10):10383-91.

33. Sola D, Rossi L, Schianca GP, Maffioli P, Bigliocca M, Mella R, et al. Sulfonylureas and their use in clinical practice. Arch Med Sci. 2015 Aug 12;11(4):840-8. doi: 10.5114/aoms.2015.53304.

34. Garratt KN, Brady PA, Hassinger NL, Grill DE, Terzic A, Holmes DR Jr. Sulphonylurea drugs increase early mortality in patients with diabetes mellitus after direct angioplasty for acute myocardial infarction. J Am Coll Cardiol. 1999 Jan;33:119-24. doi: 10.1016/s0735-1097(98)00557-9.

35. Terao Y, Ayaori M, Ogura M, Yakushiji E, Uto-Kondo H, Hisada T, et al. Effect of sulfonylurea agents on reverse cholesterol transport in vitro and vivo. J Atheroscler Thromb. 2011;18(6):513-30. doi: 10.5551/jat.7641.

36. Davies MJ, D'Alessio DA, Fradkin J, Kernan WN, Mathieu C, Mingrone $\mathrm{G}$, et al. Management of hyperglycemia in type 2 diabetes, 2018 A consensus report by the American Diabetes Association (ADA) and the European Association for the Study of Diabetes (EASD). Diabetes Care. 2018 Dec;41(12):2669-701. doi: 10.2337/dci18-0033.

37. Scheen AJ. The safety of gliptins: updated data in 2018. Expert Opin Drug Saf. 2018 Apr;17:387-405. doi: 10.1080/14740338.2018.1444027.

38. Patti AM, Giglio RV, Papanas N, Rizzo M, Rizvi AA. Future perspectives of the pharmacological management of diabetic dyslipidemia. Expert Rev Clin Pharmacol. 2019 Feb;12(2):129-43. doi: $10.1080 / 17512433.2019 .1567328$.

39. Golshahi J, Validi E, Akbari M. The association between fasting serum insulin, apo-lipoproteins level, and severity of coronary artery involvement in non-diabetic patients. Adv Biomed Res. 2014 Sep 12;3:192. doi: 10.4103/2277-9175.140624.

40. Sokolova LK, Belchina YuB, Pushkarev VV, Cherviakova SA, Vatseba TS, Kovzun OI, et al. The effect of metformin treatment on the level of GLP-1, NT-proBNP and endothelin-1 in patients with type 2 diabetes mellitus. Int J Endocrinol. 2020 Aug;16(8):26-31. doi: $10.22141 / 2224-0721.16 .8 .2020 .222882$.

41. Sokolova LK, Belchina YB, Pushkarev VV, Cherviakova SA, Vatseba TS, Kovzun OI, et al. The level of endothelin-1 in the blood of patients with diabetes, treated with hypoglycemic drugs. Endokrynologia. 2020 Oct 6;25(3):201-6. doi: 10.31793/16801466.2020. 25-3.201. 


\section{The level of apolipoprotein $A 1$ in patients with diabetes mellitus and comorbid diseases on the background of COVID-19}

\section{L.K. Sokolova, Y.B. Belchina, S.A. Cherviakova, V.V. Pushkarev, O.V. Furmanova, O.I. Kovzun, V.M. Pushkarev, M.D. Tronko}

SI «V.P. Komisarenko Institute of Endocrinology and Metabolism of the National Academy of Medical Sciences of Ukraine»

\begin{abstract}
Increased levels of high-density lipoprotein cholesterol ( $\mathrm{HDL}-\mathrm{C})$ and apolipoprotein A1 (ApoA1) in plasma is associated with a reduced risk of developing cardiovascular diseases (CVD). In addition to its potential cardioprotective function, $\mathrm{HDL}$ and ApoA1, the main HDL apolipoprotein, also have antidiabetic properties. Aim. The aim of the study was to determine the level of ApoA1 in the blood of patients ( $n=81$ ) with diabetes, COVID-19, other comorbidities, as well as the effect of hypoglycemic drugs on apolipoprotein levels. Material
\end{abstract} and methods. ApoA1 was determined using enzyme-linked immunosorbent assay (ELISA) kits (Elabscience, USA). The measurements were performed at an optical wavelength of $450 \mathrm{~nm}$. Results. The level of ApoA1 in the blood of patients with diabetes and especially with COVID-19 was significantly lower than in the blood of healthy people. The level of ApoA1 is affected by comorbidities. Chronic autoimmune thyroiditis, chronic renal failure and arterial hypertension lead to a probable decrease in blood lipoprotein levels. Treatment with metformin, either in combination with other drugs (mainly insulin) or as monotherapy, does not significantly affect the level of ApoA1 compared to the entire group average. In patients treated with sulfonylurea, the level of ApoA1 is significantly lower than the average level for the group and the norm. A significant positive effect on the amount of ApoA1 in plasma was observed in patients treated with a combination of drugs with sodium/glucose cotransporter 2 inhibitors and especially dipeptidyl peptidase-4 inhibitors. Possible mechanisms of apoA1 decrease in COVID-19 and diabetes are discussed. Conclusion. Thus, the level of ApoA1 may be one of the promising markers of severe COVID-19.

Keywords: apolipoprotein A1, COVID-19, diabetes mellitus, cardiovascular diseases, hypoglycemic agents.

\section{Уровень аполипопротеина A1 у больных сахарным диабетом и коморбидные заболевания на фоне COVID-19}

\section{Л.К. Соколова, Ю.Б. Бельчина, С.А. Червякова, В.В. Пушкарев, О.В. Фурманова, Е.И. Ковзун, В.М. Пушкарев, М.Д. Тронько.}

ГУ «Институт эндокринологии и обмена веществ им. В.П. Комиссаренко НАМН Украины»

Резюме. Повышенный уровень холестерина липопротеинов высокой плотности (ЛПВП) и аполипопротеина А1 (AроA1) в плазме ассоциируется с пониженным риском развития сердечно-сосудистых заболеваний (СС). Кроме потенциальной кардиопротекторной функции, ЛПВП и АроА1, основные аполипопротеины ЛПВП, также имеют противодиабетические свойства. Цель. Целью исследования было определение уровня АроА1 в крови больных сахарным диабетом (СД), коронавирусной инфекцией 2019 года (COronaVlrus Disease 2019, COVID-19), другими сопутствующими заболеваниями ( $n=81)$, а также влияние сахароснижающих препаратов на уровень аполипопротеина. Материал и методы. АроА1 определяли с помощью наборов для иммуноферментного анализа («Elabscience», США). Измерения проводили при оптической длине волны 450 нм. Результаты. Уровень АроА1 в крови больных СД и, особенно, COVID-19 был значительно ниже, чем в крови здоровых людей. На уровень АроА1 влияют сопутствующие заболевания. Хронический аутоиммунный тиреоидит (ХАТ) хроническая почечная недостаточность (ХПН) и артериальная гипертензия (АГ) приводят к достоверному снижении уровня липопротеина в крови. Лечение метформином в сочетании с другими препаратами (преимущественно инсулином), либо в виде монотерапии существенно не влияет на уровень АроА1 по сравнению со средним показателем для всей группы. У больных, получавших сульфонилмочевину (СС), уровень АроА1 значительно ниже среднего уровня для группы и нормы. Существенное положительное влияние на количество АроА1 в плазме наблюдалось у больных, получавших комбинацию препаратов с ингибиторами натрийзависимого котранспортера глюкозы-2 (sodium/glucose cotransporter 2 inhibitors, iSGLT2) и, особенно, ингибиторами дипептидилпептидазы-4 (dipeptidyl peptidase-4 inhibitors, DPP-4) Обсуждаются возможные механизмы снижения АроА1 в условиях COVID-19 и диабета. Вывод. Таким образом, уровень АроA1 может быть одним из перспективных маркеров тяжелого COVID-19.

Ключевые слова: аполипопротеин A1, COVID-19, сахарный диабет, сердечно-сосудистые заболевания, гипогликемические средства.

Для цитування: Соколова ЛК, Бельчіна ЮБ, Черв'якова СА, Пушкарьов ВВ, Фурманова ОВ, Ковзун ОІ, Пушкарьов ВМ, Тронько МД Рівень аполіпопротеїну А1 у хворих на цукровий діабет і коморбідні захворювання на тлі COVID-19. Ендокринологія. 2021;26(3):263270. DOI: 10.31793/1680-1466.2021.26-3.263.

Адреса для листування: Пушкарьов Володимир Михайлович, pushkarev.vm@gmail.com, ДУ «ннститут ендокринології та обміну речовин ім. В.П. Комісаренка НАМН України», вул. Вишгородська, 69, Київ 04114, Україна.

Відомості про авторів: Соколова Любов Костянтинівна, д-р мед. наук, старший науковий співробітник, завідувачка відділу діабетології, ORCID: 0000-0003-0011-0106; Бельчіна Юлія Богуславівна, канд. мед. наук, завідувачка науково-організаційного відділу, ORCID: 0000-0002-4289-8977; Черв'якова Світлана Анатоліївна, мол. наук. співр. відділу діабетології, ORCID: 0000-0002-6917-5736; Пушкарьов Віктор Володимирович, канд. біол. наук, старший науковий співробітник відділу фундаментальних і прикладних проблем ендокринології, ORCID: 0000-0001-5940-5510; Фурманова Ольга Валентинівна, мол. наук. співр. відділу профілактичної діабетології, головний лікар клініки, ORCID 0000-0002-9414-7761; Ковзун 
COVID-19

Олена Ігорівна, д-р біол. наук, чл.-кор. НАМН України, заступник директора Інституту з наукових питань, ORCID: 0000-0001-81647671; Пушкарьов Володимир Михайлович, д-р біол. наук, старш. наук. співроб., головний науковий співробітник відділу фундаментальних і прикладних проблем ендокринології, ORCID: 0000-00030347-7771; Тронько Микола Дмитрович, д-р мед. наук, чл.-кор. НАН України, акад. НАМН України, завідувач відділу фундаментальних і прикладних проблем ендокринології, директор Інституту, ORCID: 0000-0001-7421-0981.

Особистий внесок: Соколова Л.К. і Пушкарьов В.М. - аналіз даних, аналіз літературних джерел і написання тексту; Черв'якова С.А., Бельчіна Ю.Б. і Фурманова О.В. — підбір та клінічне обстеження пацієнтів та осіб контрольної групи, збір і підготовка біоматеріалів; Пушкарьов В.В. - проведення лабораторних досліджень, оформлення статті та переклад; Ковзун О.І. — написання і редагування тексту; Тронько М.Д. - ідея роботи й консультація під час редагування статті.

Фінансування: стаття підготовлена в рамках бюджетного фінансування НАМН України за планом науково-дослідних робіт ДУ «ннститут ендокринології та обміну речовин ім. В.П. Комісаренка НАМН України».

Декларація з етики: автори задекларували відсутність конфлікту інтересів і фінансових зобов'язань.

Стаття: надійшла до редакції 23.09 .2021 р.; перероблена 30.09.2021 р.; прийнята до друку 01.10.2021 р.; надрукована 20.10.2021 p.

For citation: Sokolova LK, Belchina YB, Cherviakova SA, Pushkarev VV, Furmanova OV, Kovzun OI, Pushkarev VM, Tronko MD. The level of apolipoprotein A1 in patients with diabetes mellitus and comorbid diseases on the background of COVID-19. Endokrynologia. 2021;26(3):263-270. DOI: 10.31793/1680-1466.2021.26-3.263.

Correspondence address: Pushkarev Volodymyr Mykhaylovych, pushkarev.vm@gmail.com, SI «V.P. Komisarenko Institute of Endocrinology and Metabolism of the NAMS of Ukraine», 69, Vyshgorodska st., Kyiv 04114, Ukraine.

Information about the authors: Sokolova Lyubov Konstyantynivna, Doctor of Medical Sciences, Senior Research Fellow, Head of Diabetology Department, ORCID: 0000-0003-0011-0106; Belchina Yuliya Boguslavivna, MD, Head of the Research and Organization Department, ORCID: 0000-0002-4289-8977; Cherviakova Svitlana Anatoliyivna, Junior Researcher of Diabetology Department, ORCID: 0000-0002-6917-5736; Pushkarev Viktor Volodymyrovych, PhD in Biology, Senior Researcher of the Fundamental and Applied Problems of Endocrinology Department, ORCID: 0000-0001-5940-5510; Furmanova Olga Valentynivna, Junior Researcher of the Department of Preventive Diabetology, Chief Physician of the Clinic, ORCID 0000-0002-9414-7761; Kovzun Olena Ihorivna, Doctor of Biological Sciences, Corresponding Member of the NAMS of Ukraine, Deputy Director for Research of the Institute, ORCID: 0000-0001-8164-7671; Pushkarev Volodymyr Mykhaylovych, Doctor of Biological Sciences, Senior Research Fellow, Chief Researcher of the Fundamental and Applied Problems of Endocrinology Department, ORCID: 00000003-0347-7771; Tronko Mykola Dmytrovych, Doctor of Medical Sciences, Professor, Corresponding Member of the NAS of Ukraine, Academician of the NAMS of Ukraine, Head of the Department of Fundamental and Applied Problems of Endocrinology and Director of the Institute, ORCID: 0000-0001-7421-0981.

Personal contribution: Sokolova L.K. and Pushkarev V.M. - data analysis, analysis of literary sources and text writing; Cherviakova S.A.,
Belchina Yu.B. and Furmanova O.V. - selection and clinical examination of patients and persons of the control group, collection and preparation of biomaterials; Pushkarev V.V. - laboratory research, article preparation, translation; Kovzun O.I. - writing and editing text; Tronko M.D. - Idea of work and consultation when editing an article. Funding: the article was prepared within the budget funding of the National Academy of Medical Sciences of Ukraine according to the plan of research work of the SI «V.P. Komisarenko Institute of Endocrinology and Metabolism of the NAMS of Ukraine».

Declaration of ethics: the authors declared the absence of a conflict of interest and financial obligations.

Article: received 23 September 2021; revised 30 September 2021; accepted 01 October 2021; published 20 October 2021.

Для цитирования: Соколова ЛК, Бельчина АБ, Червякова СА, Пушкарев ВВ, Фурманова ОВ, Ковзун ОИ, Пушкарев ВМ, Тронько МД. Уровень аполипопротеина А1 у больных сахарным диабетом и коморбидные заболевания на фоне COVID-19. Эндокринология. 2021;26(3):263-270. DOI: 10.31793/1680-1466.2021.26-3.263.

Адрес для переписки: Пушкарев Владимир Михайлович, pushkarev.vm@gmail.com, ГУ «Институт эндокринологии и обмена веществ им. В.П. Комиссаренко НАМН Украины», ул. Вышгородская, 69, Киев 04114, Украина.

Сведения об авторах: Соколова Любовь Константиновна, д-р мед. наук, старший научный сотрудник, заведующая отделом диабетологии, ORCID: 0000-0003-0011-0106; Бельчина Юлия Богуславовна, канд. мед. наук, заведующая научно-организационного отдела, ORCID: 0000-0002-4289-8977; Червякова Светлана Анатольевна, мл. науч. сотр. отдела профилактической диабетологии, ORCID: 0000-0002-6917-5736; Фурманова Ольга Валентиновна, мл. науч. сотр. отдела диабетологии, главный врач клиники, ORCID 0000-0002-9414-7761; Пушкарев Виктор Владимирович, канд. биол. наук, ст. науч. сотр. отдела фундаментальных и прикладных проблем эндокринологии, ORCID: 0000-0001-5940-5510; Ковзун Елена Игоревна, д-р биол. наук, чл.-корр. НАMH Украины, заместитель директора Института по науке, ORCID: 0000-0001-81647671; Пушкарев Владимир Михайлович, д-р биол. наук, ст. науч. сотр., главный научный сотрудник отдела фундаментальных и прикладных проблем эндокринологии, ORCID: 0000-00030347-7771; Тронько Николай Дмитриевич, д-р мед. наук, чл.-корр. НАН Украины, акад. НАМН Украины, заведующий отделом фундаментальных и прикладных проблем эндокринологии, директор Института, ORCID: 0000-0001-7421-0981.

Личный вклад: Соколова Л.К. и Пушкарев В.М. - анализ данных, анализ литературных источников и написание текста; Червякова С.А., Бельчина Ю.Б. и Фурманова О.В. - подбор и клиническое обследование пациентов и лиц контрольной группы, сбор и подготовка биоматериалов; Пушкарев В.В. - проведение лабораторных исследований, оформление статьи и перевод; Ковзун Е.И. - написание и редактирование текста; Тронько Н.Д. идея работы и консультация при редактировании статьи.

Финансирование: статья подготовлена в рамках бюджетного финансирования НАМН Украины по плану научно-исследовательских работ ГУ «Институт эндокринологии и обмена веществ им. В.П. Комиссаренко НАМН Украины».

Декларация по этике: авторы задекларировали отсутствие конфликта интересов и финансовых обязательств.

Статья поступила в редакцию 23.09 .2021 г.; переделана 30.09.2021 г;; принята К печати 01.10.2021 г.; напечатана 20.10. 2021 г. 